\title{
Konsep HIV/AIDS Dan Penelitian Terkait Keperawatan
}

\author{
Jek Amidos Pardede \\ jekpardedemi@rocketmail.com
}

\section{A. Konsep HIV/AIDS}

\section{Latar Belakang HIV/AIDS}

Negara peringkat pertama yang memiliki penduduk yang positive HIV/AIDS adalah Region Sub Sahara, dan pada peringkat kedua didudukioleh Asia yang memiliki jumlah kasus sebanyak 36.9 juta (UNAIDS, 2017). HIV/AIDS telah menjadi masalah kesehatan tertinggi dunia, hingga saat ini HIV/AIDS telah menelan korban lebih dari 34 juta jiwa di Afrika. Pada tahun 2014 ada 1,2 juta orang meninggal karena terkena HIV/AIDS di Afrika. Hingga akhir 2014 ada sekitar 36,9 juta orang hidup dengan HIV/AIDS, Afrika menjadi wilayah paling dampak terkena penyakit HIV/AIDS, afrika memiliki 25.8 juta orang hidup dengan HIV/AIDS dan Afrika menyumbang hampir 70\% dari total global infeksi HIV/AIDS. Menurut laporan UNAIDS, pada akhir 2017 ada sekitar 36,9 juta orang yang hidup dengan HIV/AIDS alias ODHA. Namun dari total populasi itu, hanya sekitar $75 \%$ orang yang menyadari mereka mengidap kondisi ini. Laporan tersebut juga mencatat sekitar 940.000 orang di dunia meninggal akibat penyakit yang muncul sebagai komplikasi AIDS.

\section{Definisi HIV/AIDS}

HIV/AIDS merupakan penyakit defisiensi imun sekunder yang paling umum di duniadan sekarang menjadi masalah epidemik dunia yang serius (Ignatavicius \& Workman, 2010). Data tercatat menunjukkandanterdapat 742 kasus HIV/AIDS dengan 175 orang meninggal duniasejak September 2009 (Margono, 2010). Stigma terhadap ODHA tergambar dalam sikap sinis, perasaan ketakutan yang berlebihan, dan pengalaman negatif terhadap ODHA (Shaluhiyah, 2015). Stigma membuat ODHA diperlakukan secara berbeda dengan orang lain. Diskriminasi terkait HIV adalah suatu tindakan yang tidak adil pada seseorangyang secara nyata atau diduga mengidap HIV (Herek, Capitanio, \& Widaman, 2002). 


\section{Tanda Dan Gejala HIV/AIDS}

Infeksi HIV pada umumnya tidak menampakkan wujud yang jelas di awal masa paparan. Kebanyakan ODHA tidak menunjukkan tanda atau gejala HIV/AIDS yang khas dalam beberapa tahun pertama terinfeksi. Infeksi HIV umumnya memakan waktu hingga 2 sampai 15 tahun sampai bisa memunculkan gejala pasti. HIV tidak akan langsung merusak organ tubuh Anda. Virus tersebut perlahan menyerang sistem kekebalan tubuh dan melemahkannya secara bertahap sampai kemudian tubuh menjadi rentan diserang penyakit, terutama infeksi. Gejala awal HIV umumnya mirip dengan infeksi virus lainnya, yaitu: demam, sakit kepala, kelelahan, nyeri otot, kehilangan berat badan secara perlahan, dan pembengkakan kelenjar getah bening di tenggorokan, ketiak, atau pangkal paha. Jika HIV dibiarkan, kondisi ini bisa berubah semakin parah menjadi AIDS.

\section{Penyebab HIV/AIDS}

HIV adalah penyakit infeksi yang disebabkan oleh Human Immunodeficiency Virus. Adapun AIDS adalah kondisi yang terdiri dari kumpulan gejala terkait pelemahan sistem imun ketika infeksi HIV sudah berkembang parah dan tidak ditangani dengan baik. Menurut Center for Disease Control and Prevention (CDC), penularan virus HIV dari pengidap hanya bisa diperantarai oleh cairan tubuh seperti darah, air mani, cairan pra-ejakulasi, cairan rektal (anus), cairan vagina, dan ASI yang berkontak langsung dengan luka terbuka di selaput lendir, jaringan lunak, atau luka terbuka di kulit luar tubuh orang sehat. Jalur penularan virus umumnya terjadi dari hubungan seks tanpa kondom (penetrasi vaginal, seks oral, dan anal). Ingat, penularan HIV hanya bisa terjadi dengan syarat, Anda sebagai orang yang sehat memiliki luka terbuka atau lecet di organ seksual, di mulut, atau di kulit. Biasanya perempuan remaja cenderung lebih rentan terhadap risiko infeksi HIV karena selaput vagina mereka lebih tipis sehingga lebih rentan lecet dan terluka dibandingkan wanita dewasa. Penularan HIV lewat seks anal juga termasuk lebih rentan karena jaringan anus tidak memiliki lapisan pelindung layaknya vagina, sehingga lebih mudah sobek akibat gesekan.

Selain dari paparan antar cairan dengan luka lewat aktivitas seks, penularan HIV juga dapat terjadi jika cairan terinfeksi tersebut disuntikkan langsung ke pembuluh darah, misalnya dari:

> Pemakaian jarum suntik secara bergantian dengan orang yang terkontaminasi dengan Human Immunodeficiency Virus.

> Menggunakan peralatan tato (termasuk tinta) dan tindik (body piercing) yang tidak disterilkan dan pernah dipakai oleh orang dengan kondisi ini. 
> Memiliki penyakit menular seksual (PMS) lainnya seperti klamidia atau gonore. Virus HIV akan sangat mudah masuk saat sistem kekebalan tubuh lemah.

> Ibu hamil pengidap HIV/AIDS dapat menularkan virus aktif kepada bayinya (sebelum atau selama kelahiran) dan saat menyusui.

HIV tidak tertular melalui kontak sehari-hari seperti: bersentuhan, berjabat tangan, bergandengan, berpelukan, cipika-cipiki, batuk dan bersin, mendonorkan darah ke orang yang terinfeksi lewat jalur yang aman, menggunakan kolam renang atau dudukan toilet yang sama, berbagi sprei, berbagi peralatan makan atau makanan yang sama dan dari hewan, nyamuk, atau serangga lainnya.

\section{Pengobatan HIV/AIDS}

HIV/AIDS tidak bisa disembuhkan karena tidak ada obatnya. Namun, gejala penyakit bisa dikendalikan dan sistem imun bisa ditingkatkan dengan pemberian terapi antiretoviral (ARV). Obat ARV tidak dapat menyembuhkan, tetapi bisa membantu orang dengan HIV hidup lebih lama dan lebih sehat. Selain itu, ARV juga membantu mengurangi risiko penularan HIV. Terapi ARV adalah sekumpulan obat yang biasanya digunakan untuk mengobati infeksi akibat penyakit HIV. Tujuan utama obat ARV adalah mencegah dan mengurangi jumlah HIV dalam tubuh dan menghambat virus dalam memperbanyak diri. Dengan begitu, jumlah virusnya di dalam tubuh tidak terus bertambah. Berkurangnya virus HIV memberi kesempatan bagi sistem kekebalan tubuh untuk bisa pulih dan cukup kuat untuk melawan infeksi dan kanker. Selain itu, ketika jumlah virusnya rendah dan tidak terdeteksi, kemungkinan untuk menularkan infeksi $H I V$ ini ke orang lain pun berkurang.

\section{Pengobatan di Rumah}

Berikut gaya hidup, pengobatan rumahan, serta pencegahan yang dapat membantu Anda mengatasi infeksi virus HIV/AIDS: Makan makanan dengan gizi seimbang dan memperbanyak sayur, buah, biji-bijian, dan protein tanpa lemak; Cukup istirahat; Rutin berolahraga; Menghindari obat-obatan terlarang termasuk alcohol; Berhenti merokok; Melakukan berbagai cara untuk mengelola stres seperti meditasi atau yoga; Mencuci tangan dengan air bersih dan sabun setiap habis memegang hewan peliharaan; Menghindari daging mentah, telur mentah, susu yang tidak dipasteurisasi, dan makanan laut mentah; Melakukan vaksin yang tepat untuk mencegah infeksi seperti radang paru dan flu.

Jika_positif terkena HIV, dapat menularkan virus ke orang lain meski tubuh tidak menunjukkan gejala apapun. Untuk itu, lindungi diri dan orang lain dan cegah 
penyebaran HIV dengan cara: Selalu menggunakan kondom saat berhubungan seks vagina, oral, atau anal dan tidak berbagi jarum atau peralatan obat lainnya. Jika mengalami HIV dan hamil, berkonsultasilah dengan dokter yang memiliki pengalaman tentang pengobatan infeksi HIV. Tanpa pengobatan, sekitar 25 dari 100 bayi yang lahir dari ibu dengan HIV juga terinfeksi. Namun, ibu hamil dapat secara langsung mengurangi risiko penularan kepada calon anaknya dengan rutin menggunakan obatobatan HIV/AIDS, melahirkan lewat operasi caesar, dan tidak menyusui ASI eksklusif. Jika memiliki pertanyaan, silakan berkonsultasi dengan dokter demi lebih memahami solusi terbaik..

\section{B. Penelitian Terkait Keperawatan Pada ODHA}

\section{Masalah Kecemasan}

Kecemasan merupakan suatu respon psikologis maupun fisiologis individu terhadap suatu keadaan yang tidak menyenangkan, atau reaksi atas situasi yang dianggap mengancam (Hulu \& Pardede, 2016). Ansietas adalah keadaan emosi dan pengalaman subyektif individu, tanpa objek yang spesifik karena ketidaktahuan dan mendahului semua pengalaman yang baru seperti masuk sekolah,pekerjaan baru,atau melahirkan anak (Stuart,2009). Terdapat pengaruh yang signifikan antara Pengaruh hipnotis lima jari Terhadap tingkat kecemasan Pada ODHA dengan nilai $p=0,002(p<0,05)$. Terapi perilaku religious berperngaruh dalam menurunkan kecemasan terhadap kematian pada penederita HIV/AIDS (Irawati, Subandi \& Kumolohadi, 2011). Hasil penelitian Laksmi, et al (2020). Terapi Reiki memiliki pengaruh terhadap tingkat kecemasan subjek penelitian dengan $\mathrm{p}$ value $=0,017$.

\section{Masalah Ketidakberdayaan}

Ketidakberdayaan merupakan persepsi individu bahwa segala tindakannya tidak akan mendapatkan hasil atau suatu keadaan dimana individu kurang dapat mengendalikan kondisi tertentu atau kegiatanyang baru dirasakan (Pardede, 2020). Menurut Wilkinson (2007) ketidakberdayaan merupakan persepsi seseorang bahwa tindakannya tidak akan mempengaruhi hasil secara bermakna, kurang penggendalian yang dirasakan terhadap situasi terakhir attau yang baru saja terjadi. Hasil penelitian Kartono (2017). Kondisi ketidakberdayaan akan memberi efek yang lebih komplek dan luas mulai semakin merebaknya penyebaran virus HIV/AIDS, kematian yang cepat, hingga menjadi beban sosial, baik keluarga, komunitas maupun negara.

\section{Masalah Harga Diri}

Harga diri yang tinggi dikaitkan dengan kecemasan yang rendah, efektif dalam kelompok dan penerimaan orang lain terhadap dirinya, sedangkan masalah kesehatan dapat menyebabkan harga diri, sehingga harga diri dikaitkan dengan hubungan 
interperonal yang buruk dan beresiko terjadinya depresi sehingga perasaan negatif mendasari hilangnya kepercayaan diri dan harga diri individu dan menggambarkan gangguan harga diri (Wandono, 2017). Menurut Pardede, Hutajulu, \& Pasaribu (2020). Pasien dengan HIV/AIDS masih memiliki harga diri yang tinggi sama halnya dengan orang yang belum terkena penyakit HIV/AIDS. Tingginya harga diri pasien HIV/AIDS berawal dari dukunganorang disekitarnya. Untuk itu, perlu dukungan dan motivasi lagi kepada pasien baik dari keluarga sendiri maupun dari orang lain. Hasil penelitian yang dilakukan terdapat hubungan yang signifikan antara harga diri dengan depresi pasien HIV/AIDS dengan nilai $p$ value $=0.000$ dengan kekuatan hubunganr=0.603.

\section{Referensi}

1. UNAIDS. Global HIV Statistics', Fact sheet. 2017, p. 6. Available at: http://www.unaids.org/en/resources/fact-sheet

2. Pardede JA, Simanjuntak GV, Waruwu JF. Penurunan Tingkat Kecemasan Pasien HIV/AIDS melalui Terapi Hipnotis Lima Jari. Coping: Community of Publishing in Nursing. 2020;8:85-90.

3. Irawati D, Subandi MA, Kumolohadi R. Terapi kognitif perilaku religius untuk menurunkan kecemasan terhadap kematian pada penderita HIV/AIDS. Jurnal Intervensi Psikologi. 2011;3(2):169-86.

4. Chusna N, Nurhalina N. Tingkat Kecemasan Ibu Rumah Tangga dengan HIV Positif di Kota Palangka Raya. Jurnal Surya Medika (JSM). 2019 Feb 28;4(2):95-100.

5. Pardede JA. Self Concept with the Stress of HIV/AIDS Patients. 2020.

6. Ahdiany GN, Widianti E, Fitria N. Tingkat Kecemasan Terhadap Kematian Pada ODHA. Jurnal Keperawatan Soedirman. 2018 Mar 26;12(3):199-208.

7. Simanjuntak GV, Saragih M, Hasibuan EK, Pardede JA. Stop Stigma Dan Diskriminasi ODHA di Kota Medan. Jurnal Abdimas Mutiara. 2020 Mar 13;1(1):24-9.

8. Laksmi AS, Candra IW, Harini IG, Ruspawan ID. Pengaruh Terapi Reiki Terhadap Kecemasan Pada Orang Dengan Hiv/Aids (Odha). Jurnal Gema Keperawatan. 2020 Jun $20 ; 13(1)$. 
9. Stuart,G.W. Principles and Practice of PsychyatricNursing. $8^{\text {th }}$ edition. Missouri: Mosby.2009

10. Wilkinson K. The concept of hope in life-threatening illness. Professional nurse (London, England). 2007Jul;11(10):659.

11. Kartono R. Ketidakberdayaan (Powerlessness) Orang Dengan Hiv/Aids (Odha) Di Kota Malang. Sosio Konsepsia. 2017 May 17;16(3):295-313.

12. Wandono, W. A., \& Arum Pratiwi, S. Upaya Peningkatan Harga Diri Rendah Pada Pasien Depresi (Doctoral dissertation, Universitas Muhammadiyah Surakarta). 2017.

13. Herek GM, Capitanio JP, Widaman KF. HIVrelated stigma and know-ledge in the United States: prevalence and trends, 1991-1999. AmericanJournal of Public Health. 2002; 92 (3): $371-7$

14. Shaluhiyah Z, Musthofa SB, Widjanarko B. Stigma masyarakat terhadaporang dengan HIV/AIDS. Kesmas: National Public Health Journal. 2015 May 1;9(4):333-9.

15. Pardede JA, Hutajulu J, Pasaribu PE. Harga Diri dengan Depresi Pasien Hiv/aids. Jurnal Media Keperawatan: Politeknik Kesehatan Makassar. 2020;11(01).

16. Kambu Y, Waluyo A, Kuntarti K. Umur orang dengan HIV AIDS (ODHA) berhubungan dengan tindakan pencegahan penularan HIV. Jurnal Keperawatan Indonesia. 2016 Nov 18;19(3):200-7. 